\title{
Geochemical characteristics of the Chang7 organic-rich fine-grained sedimentary rocks and its relationship with the tight oil in Longdong area, Northwest China
}

\author{
Yongliang Gao ${ }^{1,2} \cdot$ Zhigang Wen $^{1,2} \cdot$ Yaohui Xu ${ }^{1,2} \cdot$ Huanxin Song ${ }^{3} \cdot \mathrm{Wei}^{4}{ }^{4} \cdot$ Yamin $\mathrm{Yu}^{5} \cdot$ Changwei Ke $^{5}$
}

Received: 15 September 2019 / Accepted: 16 April 2020 / Published online: 24 April 2020

(c) The Author(s) 2020

\begin{abstract}
In order to study the geochemical characteristics of fine-grained sedimentary rocks and clarify its relationship with the tight oil reservoir, the Chang7 Member of Triassic Yanchang Formation in Longdong area was taken as an example to be studied by rock pyrolysis, isotopic determination, maceral analysis, gas chromatography and gas chromatography-mass spectrometry. Lacustrine organic-rich fine-grained sedimentary rocks can be divided into organic-rich shale and organic-rich mudstone according to their lithology and texture. The results show that the organic-rich shale was deposited in a quiet and anoxic deep lacustrine environment, the organic matter was of high abundance and mainly sourced from plankton and benthic algae (type $\mathrm{I}-\mathrm{II}_{1}$ ). Organic-rich mudstone mainly deposited in the semi-deep lacustrine environment, where the water was relatively shallow and the salinity was low, the organic matter was of low abundance and came from the mixed source of plankton and terrestrial clastic (type $\mathrm{II}_{1}-\mathrm{II}_{2}$ ). The Chang7 tight oil is widely distributed in the turbidite sand bodies, and it was mainly sourced from the Chang7 organic-rich shale.
\end{abstract}

Keywords Organic-rich fine-grained sedimentary rocks · Geochemical characteristics · Tight oil · Chang7 reservoir · Longdong area $\cdot$ Ordos basin

\section{Introduction}

With the development of tight oil exploration and research in related fields, the relationship between fine-grained sedimentary rocks and tight oil accumulation has become a hot topic in current research (Jia et al. 2012; Jiang et al. 2013; Du et al. 2014; Hao et al. 2014; Ghanizadeh et al. 2015; Pu

Zhigang Wen

yangtzeu410@163.com

1 Key Laboratory of Technology for Oil and Gas Resources, Ministry of Education, Yangtze University, Wuhan 430100, China

2 College of Resources and Environment, Yangtze University, Wuhan 430100, China

3 Hubei Collaborative Innovation Center for Unconventional Oil/Gas, Yangtze University, Wuhan 430100, China

4 Geochemical Laboratory, CNOOC Research Institute, Beijing 100027, China

5 State Key Laboratory of Petroleum Resources and Prospecting, China University of Petroleum, Beijing 102249, China et al. 2016; Hu et al. 2018). Fine-grained sediments refer to clay-grade and silt-grade sediments with particle size smaller than $62 \mu \mathrm{m}$. Their components mainly include clay minerals, carbonate minerals, silt and organic matter. Rocks composed of fine-grained sediments are called fine-grained sedimentary rocks (Picard, 1971; Aplin et al. 2011; Jiang et al. 2017).

According to the difference of TOC, clay mineral and carbonate mineral content, fine-grained sedimentary rocks were divided into six categories: high organic shale clay stone, high organic shale limestone, medium organic shale clay stone, medium organic shale limestone, low organic shale clay stone, and low organic shale limestone (Jiang et al. 2013). According to organic matter content, fine-grained sedimentary rocks were divided into three types: organicrich fine-grained sedimentary rocks, medium-organic finegrained sedimentary rocks and organic-poor fine-grained sedimentary rocks (Zhang et al. 2017). According to the particle size, sedimentary structure and geochemical characteristics, fine-grained sedimentary rocks of Chang7 Member in Ordos Basin were divided into 4 lithofacies: oil shale facies, dark mudstone facies, sandy mudstone and 
argillaceous sandstone facies, and sandstone facies (Fu et al. 2013). Siltstone and argillaceous siltstone are developed in sandy lithofacies. The structure of these rocks is relatively tight, and tight oil resources can be formed when oil and gas are accumulated in large quantities (Pommer et al. 2015; Hu et al. 2015; Nole et al. 2016; Ko et al. 2016; Lucy et al. 2016; Zhang et al. 2018). Organic-rich fine-grained sedimentary rocks are developed in oil shale facies and dark mudstone facies. From the viewpoint of hydrocarbon generation, organic-rich fine-grained sediments play an important role in the primary accumulation of source rocks (Yang et al. 2017). It can be seen that organic-rich fine-grained sedimentary rocks, as high-quality source rocks, not only control the formation and distribution of conventional oil and gas reservoirs, but also are closely related to unconventional oil and gas resources such as tight oil and gas.

It is generally believed that the Chang7 tight oil in Ordos Basin was generated from Chang7 source rocks, but the predecessors did not give detailed conclusions about which type of source rocks contributed the most to hydrocarbon generation (Zhang et al. 2011; Deng et al. 2013; Yang et al.
2016). This paper aims to summarize the geochemical characteristics of different types of lacustrine organic-rich finegrained sedimentary rocks in Ordos Basin and analyze their relationship with the accumulation of tight oil.

\section{Geological setting}

The Ordos Basin is a multi-cyclic superimposed basin that formed on the North China Craton Basin (Xu et al. 2006). It is a large inland depression that developed on the Paleozoic Platform. The basin formed and developed in the Mesozoic Indo-China and Yanshan movement. During the late Triassic Indo-China movement, the base of Ordos Basin steadily sank and began to develop. In the early stage of Yanshan movement, strong horizontal movement occurred in the depression, forming the Thrust Structural Belt in the west and the Weibei Uplift Belt in the north (Fig. 1). In the middle and late stage of Yanshan movement, the western part of the basin was in a state of subsidence. The sedimentation center of the basin moved to the west and the Tianhuan Depression
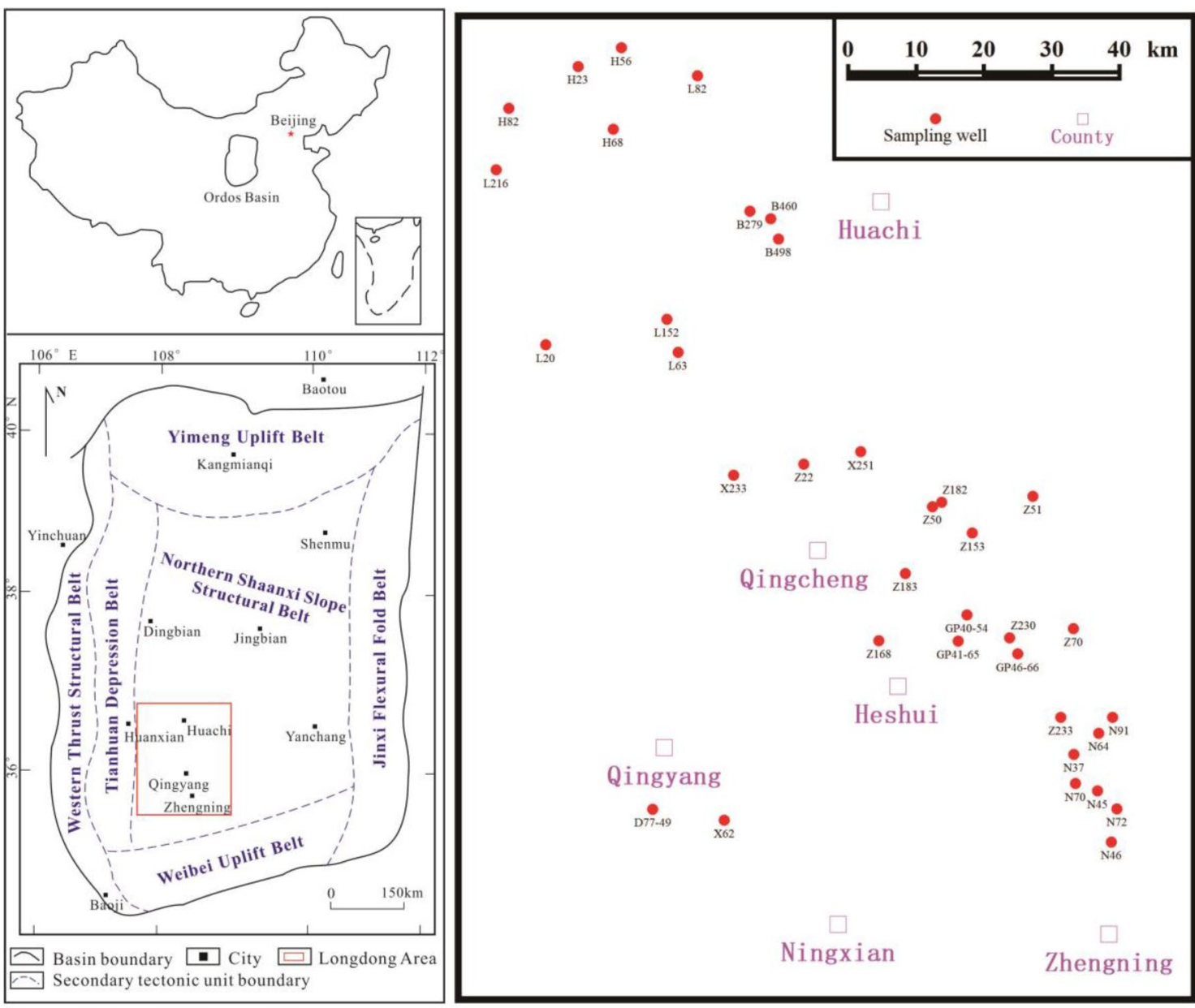

Fig. 1 Tectonic location of the study area (modified from Li 2017) 
Belt was formed. Subsequently, the Lvliang Mountain rose and formed the Jinxi Flexural Fold Belt. At the same time, Northern Shaanxi Slope Structural Belt, a large west-leaning monocline with low west and high east was formed in the central part of the basin (Fig. 1). Till then, the basin was separated from the North China Platform, and the independent Ordos Basin was formed (Zhao et al. 2012).

The basement of Ordos Basin is the Archean and Paleoproterozoic metamorphic strata. The formations are relatively complete. Only Silurian, Devonian and Lower Carboniferous Series were deduced. The main oil-bearing series is the Triassic Yanchang Formation, which is composed of terrigenous clastics and lacustrine deposits. The sandstones of Yanchang Formation are mainly fine sand and silty sand, mostly grey-green and gray, while the argillaceous rocks are mainly dark mudstone and shale ( $\mathrm{Li}$ et al. 2006). According to the characteristics of lithology, logging and paleontology, the Yanchang Formation can be divided into 10 oil-bearing members (Yang 2004), of which the Chang6 and Chang7 Member are the main stratigraphic series for tight oil exploration and development. The organic-rich fine-grained sedimentary rocks are mainly developed in the semi-deep lacustrine to deep lacustrine subfacies. The Chang7 sedimentary stage was the largest lacustrine flood stage of Ordos Basin, so the organic-rich fine-grained sedimentary rocks of Chang7 Member were the most developed. The study area, Longdong area, is located in the southwest of Ordos Basin, the southwest of Northern Shaanxi Slope Structural Belt in structure (Fig. 1).

At present, the main tight oil accumulation series found in Ordos Basin are the Chang 6 and Chang7 Members, of which the resource extent of the Chang7 tight oil is about $9 \times 10^{8} \mathrm{t}$ (according to Research Institute of Exploration and Development, PetroChina Changqing Oilfield Company). Chang7 Member is located in the lower part of Triassic Yanchang Formation (Fig. 2). And Chang7 tight oil is mainly developed in the submembers of Chang $7_{1}$ and Chang $7_{2}$. From a plane point of view, the Chang7 tight oil is mainly distributed in the delta front sandstone in Jiyuan area and turbidite sand bodies in Longdong area. In Longdong area, the Chang7 tight oil is mainly distributed in the lake center, Huanxian-Huachi-Qingyang area.

\section{Samples and methods}

The lacustrine organic-rich fine-grained sedimentary rocks are mainly developed in lakes with high productivity. Algae bloomed seasonally, and the organic matter of lacustrine facies deposited rapidly (Zhang et al. 2017). According to different lithology and structure, lacustrine organic-rich finegrained sedimentary rocks can be divided into organic-rich shale and organic-rich mudstone. Shale is mainly developed

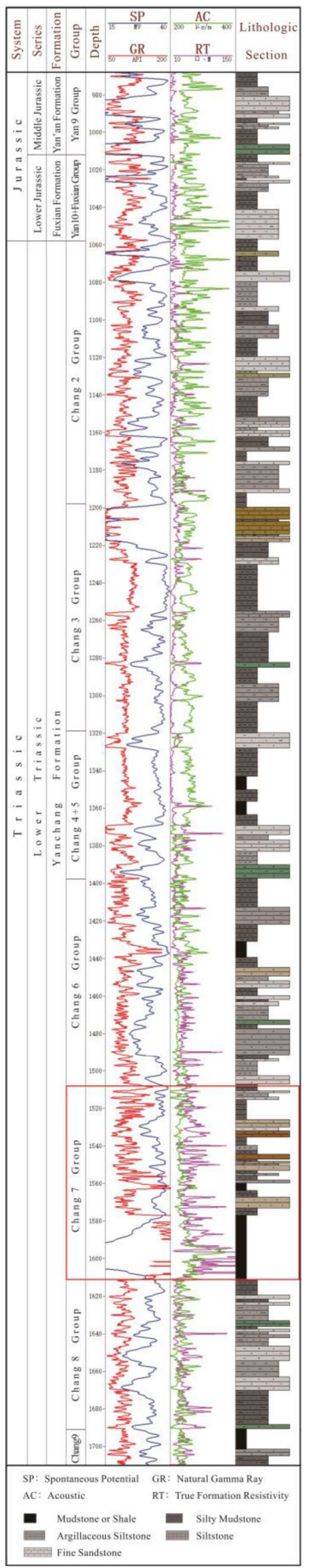

Fig. 2 Stratigraphic column of Well Z73 
in the relatively closed deep lacustrine environment with insufficient supply of terrigenous clastic material. The deposition rate is relatively low and the laminar structure is commonly found in the organic-rich shale. Mudstone is generally formed in the semi-deep lacustrine environment where the supply of terrigenous clastic material is relatively sufficient, and the deposition rate is relatively high (Yuan et al 2015). The organic-rich mudstone has no obvious laminar structure, which is the difference between mudstone and shale in structure. Based on the observation of the structure and construction of core samples, the organic-rich fine-grained sedimentary rock samples were classified (Fig. 3). Organicrich shale is mainly black with laminar structure, and the samples are fragile under stress (Fig. 3a-c). Organic-rich mudstone is mainly dark gray-black with blocky structure
(Fig. 3d, 3e), and carbonized plant debris can be found occasionally in the mudstone samples (Fig. 3f).

In order to study the characteristics of Chang7 organicrich fine-grained sedimentary rocks in Longdong area, organic petrological, and molecular geochemical experiments were carried out. Additionally, molecular geochemical experiments on tight oil samples were carried out.

\section{Organic petrological analyses}

The organic petrology experiments rely on the OGE-VI Rock-Eval Pyrolysis and Polarizing Microscope from the Key Laboratory of Technology for Oil and Gas Resources, Ministry of Education, Yangtze University and the MAT253 Stable Isotope Mass Spectrometer from the Isotope
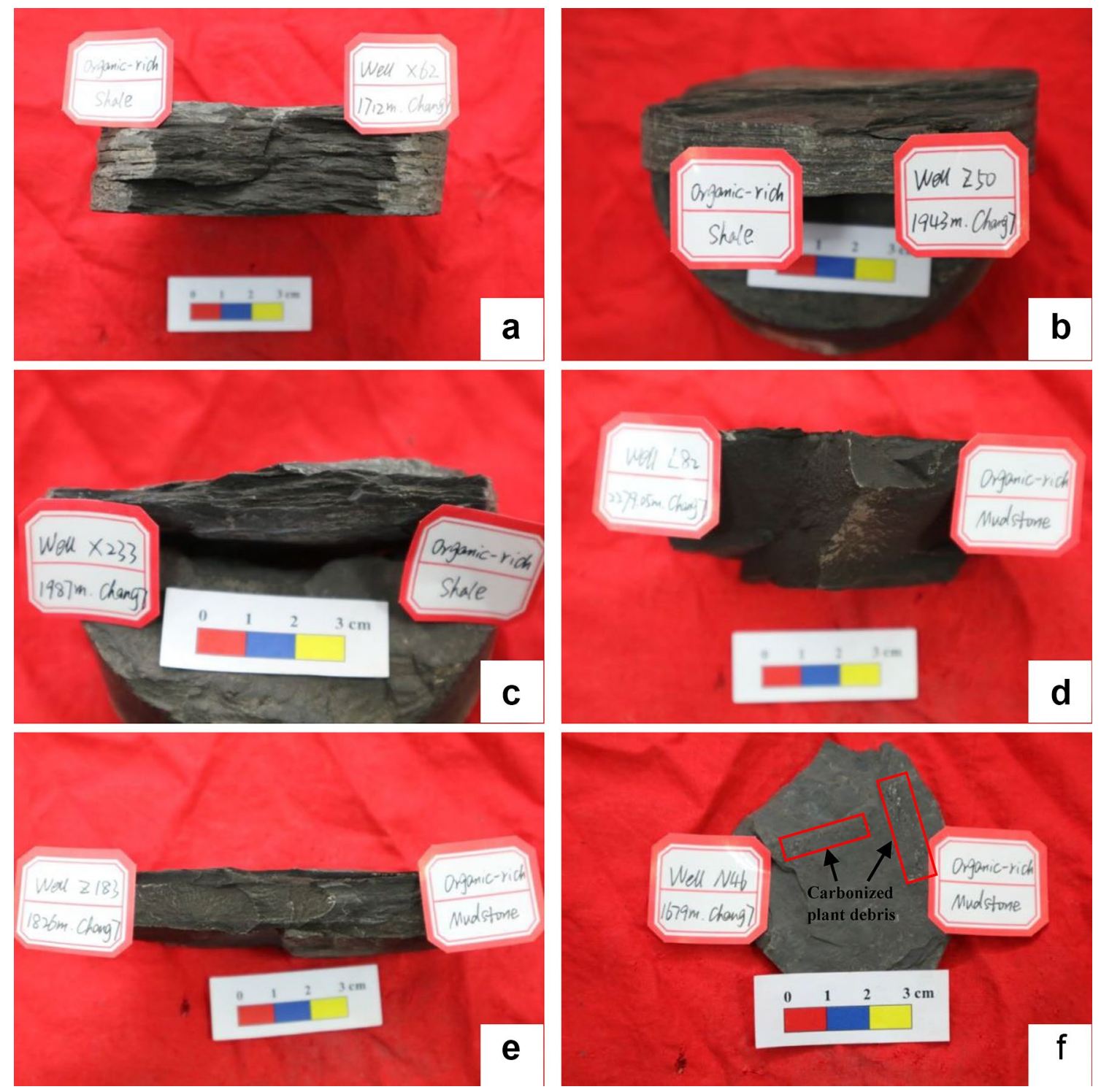

Fig. 3 Core samples of organic-rich fine-grained sedimentary rocks 
Laboratory of China University of Geosciences (Beijing). Twenty-five Chang7 organic-rich fine-grained sedimentary rock samples (14 shale samples and 11 mudstone samples) of Longdong area were selected for rock pyrolysis analysis, 10 of them ( 3 shale samples and 7 mudstone samples) for carbon stable isotope analysis, and 6 of them ( 2 shale samples and 4 mudstone samples) for kerogen macerals analysis. In order to clarify the abundance of organic matter of the samples, we used the pyrolysis parameters, total organic carbon (TOC, \%) and potential hydrocarbon generation amount $\left(S_{1}+S_{2}, \mathrm{mg} / \mathrm{g}\right)$. In order to classify the types of organic matter, the pyrolysis parameters, the highest pyrolysis peak temperature $\left(T_{\max },{ }^{\circ} \mathrm{C}\right)$ and hydrogen index $(\mathrm{HI}, \mathrm{mg} / \mathrm{g})$, the carbon stable isotope $\left(\delta^{13} \mathrm{C}, \%\right.$ ) and the kerogen type index (TI) were studied.

\section{Rock pyrolysis analysis}

The impurities, such as dust, paint and marker marks, were removed from the sample and the sample $(>5 \mathrm{~g})$ was crushed to 100 meshes. We put the sample into the drying oven to remove the water for more than $72 \mathrm{~h}$, so as to eliminate the influence of water vapor on the experimental results. Before the experiments started, we had taken two blank runs and two parallel experiments on the reference material to make sure the measured values $\left(S_{2}, S_{3}, S_{4}\right.$ and $\left.T_{\max }\right)$ could reach the required accuracy of analysis. The samples to be measured were accurately weighed $100 \mathrm{mg}$ for analysis. The hydrogen-flame ionization detector was used to detect the hydrocarbon compounds that generated from the samples during the pyrolysis process. $\mathrm{CO}_{2}$ generated from the organic matter of residual carbon was detected by thermal conductivity detector. The instrument detected the following parameters under different temperature conditions in the process of analysis: gaseous hydrocarbon $\left(S_{0}\right)$ under $90{ }^{\circ} \mathrm{C}$, residual hydrocarbon $\left(S_{1}\right)$ under $300^{\circ} \mathrm{C}$, cracking hydrocarbon $\left(S_{2}\right)$ under $300-600{ }^{\circ} \mathrm{C}, \mathrm{CO}_{2}$ produced by pyrolysis of rocks $\left(S_{3}\right)$ under $300-392{ }^{\circ} \mathrm{C}$, and carbon residue content after pyrolysis process $\left(S_{4}\right)$ under $600^{\circ} \mathrm{C}$. During the analysis, the value of $T_{\max }$ was recorded. Through calculation, rock pyrolysis parameters such as TOC, $\mathrm{HI}$ and degradation rate $(D)$ were obtained.

\section{Carbon isotope analysis}

The impurities, such as dust, paint and marker marks, were removed from the sample and the sample was crushed to 100 meshes. Each organic-rich fine-grained sedimentary rock sample was weighed at about $50 \mathrm{~g}$ and extracted by chloroform and methanol-acetone-benzene ternary solvents (MAB), then made into sample of kerogen by the kerogen automatic preparatory. The preparation process includes: distilled water immersion, acid treatment, alkali treatment, heavy liquid flotation, repeated cleaning of distilled water, freezing, chloroform cleaning and drying. The kerogen sample to be analyzed was sent to the front end of the combustion tube, and the sample was oxidized and decomposed in the high-temperature combustion zone at $800{ }^{\circ} \mathrm{C}$ after being washed out by helium. Sulfide, nitrogen oxides, halogens and other impurities produced during combustion were removed to avoid interference with carbon isotope detection. The kerogen samples were completely decomposed in about $60-180 \mathrm{~s}$. When the heating furnace was closed and helium was introduced, the $\mathrm{CO}_{2}$ was taken out and frozen in the cold trap. Then, helium and nitrogen were removed, and the purified $\mathrm{CO}_{2}$ was transferred to the isotope mass spectrometer for the detection of the carbon stable isotope value.

\section{Kerogen maceral analysis}

Kerogen samples were prepared by the same method as the carbon isotope analysis. The polyvinyl alcohol solution was made from polyvinyl alcohol and distilled water with the volume ratio of 1:9. The kerogen sample was put on the cover glass by a glass rod, appropriate amount of polyvinyl alcohol solution was added. The kerogen sample and the polyvinyl alcohol solution were mixed thoroughly. After air drying at room temperature, appropriate amount of nonfluorescent adhesive was added on the cover glass. When the sample was completely solidified, it was sent to be tested. The sample was observed with the microscope. The sample was put on the microscope stage and first viewed with 40 times objective lens. The representative particle size of the sample was chosen and used as a statistical unit. The standard for selecting representative particle is that the number of particles whose size is larger than that of representative particle should be greater than $50 \%$. So, the size of representative particle should be smaller than the median particle size in the sample. The horizon of the microscope objective lens was moved equidistantly, the center point of each horizon served as the fixed coordinate of the identified object. Sample particles entering this coordinate were identified and statistically analyzed according to the characteristics under transmitted light and fluorescence. Over 300 statistical units were identified and the percentage of each maceral was calculated according to the number of each component.

\section{Molecular geochemistry analyses}

This study of molecular geochemistry is based on the HP6890N/5975I gas chromatography-mass spectrometry (GC-MS) [with the HP-5 capillary column $(30 \mathrm{~m} \times 0.25 \mathrm{~mm} \times 0.25 \mu \mathrm{m})]$ in the Key Laboratory of Technology for Oil and Gas Resources, Ministry of Education, Yangtze University. A total of 24 samples (7 shale samples, 
11 mudstone samples and 6 oil samples) were selected for GC-MS analysis.

In gas chromatography (GC) analysis, the extracted organic-rich fine-grained sedimentary rock samples or oil samples were rinsed with hexane on the silica column to obtain saturated hydrocarbon fraction. The concentration was purged with nitrogen and transferred to chromatographic injection bottle. The sample was diluted with appropriate amount of hexane before analysis. The gas chromatographic analysis conditions are as follows: the vaporization room temperature is $300{ }^{\circ} \mathrm{C}$, the carrier gas is helium with the purity of $99.9995 \%$, the column mode is constant current with the rate of $1.0 \mathrm{~mL} / \mathrm{min}$, the injection volume is $0.5-1.0 \mu \mathrm{L}$, the split ratio is $20: 1$, the injection pulse pressure is $15.0 \mathrm{psi}$ and the duration of injection pulse is $1 \mathrm{~min}$. Chromatographic temperature program performs as follows: the temperature was kept constant at $50^{\circ} \mathrm{C}$ for $2 \mathrm{~min}$, then rose at a rate of $20^{\circ} \mathrm{C} / \mathrm{min}$ to $100{ }^{\circ} \mathrm{C}$, and rose to $310{ }^{\circ} \mathrm{C}$ at a rate of $3{ }^{\circ} \mathrm{C} / \mathrm{min}$, finally the temperature was kept constant for $15.5 \mathrm{~min}$. After the detection, the chromatograms were output, and the main peak carbon, carbon advantage index (CPI), odd-even carbon advantage index (OEP), $\mathrm{Pr} / \mathrm{Ph}, \mathrm{Pr} /$ $\mathrm{nC}_{17}, \mathrm{Ph} / \mathrm{nC}_{18}$ and other molecular geochemical parameters were calculated by the chromatogram.

In GC-MS analysis, saturated hydrocarbon fraction was prepared by chromatographic method. The conditions for gas chromatographic analysis have been stated above. The conditions of mass spectrographic analysis are as follows: the mode of ionization is electron impact, the electron energy is $70 \mathrm{eV}$, the ion source temperature is $230^{\circ} \mathrm{C}$, the quadropole temperature is $150^{\circ} \mathrm{C}$, the $\mathrm{GC} / \mathrm{MS}$ interface temperature is $280^{\circ} \mathrm{C}$, the mass scan range is $50-550$, the scan frequency is $0.77 / \mathrm{s}$, the $\mathrm{m} / \mathrm{z}$ values are $82,85,92,97,98,106,109$, $123,125,177,183,191,205,217,218,219,221,231,253$, $259,400,412,414$. After the detection, the mass chromatograms were output, and a large number of biomarker parameters were obtained through a series of data processing and calculation.

\section{Results}

\section{Rock pyrolysis parameters}

Rock pyrolysis parameters are the most basic parameters of organic geochemistry for source rocks. A study of rock pyrolysis for lacustrine organic-rich fine-grained sedimentary rocks of Chang7 Member in Longdong area was taken. Among 14 shale samples, the distribution range of TOC is $2.12-31.7 \%$, with an average of $12.48 \%$. The distribution range of $S_{1}+S_{2}$ is $10.18-117.57 \mathrm{mg} / \mathrm{g}$, with an average of $46.58 \mathrm{mg} / \mathrm{g}$. The distribution range of $\mathrm{HI}$ is $225-647 \mathrm{mg} / \mathrm{g}$, with an average of $390 \mathrm{mg} / \mathrm{g}$. Among the 11 mudstone samples, the distribution range of TOC is $1.36-13.30 \%$, with an average of $3.08 \%$. The distribution range of $S_{1}+S_{2}$ is $5.65-49.42 \mathrm{mg} / \mathrm{g}$, with an average of $12.10 \mathrm{mg} / \mathrm{g}$. The distribution range of $\mathrm{HI}$ is $77-593 \mathrm{mg} / \mathrm{g}$, with an average of $214 \mathrm{mg} / \mathrm{g}$ (Table 1).

\section{Carbon isotope and kerogen maceral parameters}

The values of stable carbon isotope of kerogen of the 3 shale samples are distributed in the range of -29.82 to $-28.02 \%$, with an average of $-28.91 \%$. The values of stable carbon isotope of kerogen of the 7 mudstone samples are ranged from $-28.70 \%$ o to $-26.40 \%$, with an average of $-27.71 \%$ o (Table 2).

Ordinarily, the macerals of kerogen mainly include sapropel, exinite, vitrinite, inertinite and amorphous components. Different components may originate from different types of organic matter. The kerogen maceral of the 2 shale samples are mainly sapropel group ( $>95 \%)$, and the TI values are all higher than 95 . The kerogen maceral of the 4 mudstone samples are mainly composed of exinite group (samples from Well Z153), vitrinite group or amorphous group (samples from Well Z50), and the type index is distributed between -61 and 40 (Table 3).

\section{GC-MS parameters}

A series of parameters were obtained by GC-MS experiments. In this study, hopane series, sterane series, pristane and phytane parameters were selected to be studied.

\section{Organic-rich fine-grained sedimentary rocks}

The distribution of hopane series of Chang7 organic-rich shale and organic-rich mudstone are of some difference in Longdong area (Table 4). Among the shale samples, the ratio of the gammacerane and the $\mathrm{C}_{30}$ hopane $\left(\mathrm{G} / \alpha \beta \mathrm{C}_{30} \mathrm{H}\right)$ is distributed in $0.11-0.23$. The homohopane index $\left[\mathrm{C}_{35} /\right.$ $\left(\mathrm{C}_{31}-\mathrm{C}_{35}\right)$ ] is distributed in $0.04-0.08$. While among the mudstone samples, the distribution range of $\mathrm{G} / \alpha \beta \mathrm{C}_{30} \mathrm{H}$ is 0.06-0.19, and that of $\mathrm{C}_{35} /\left(\mathrm{C}_{31}-\mathrm{C}_{35}\right)$ is $0.03-0.07$.

Similarly, the distribution characteristics of sterane series of organic-rich shale and mudstone of Chang7 Member in Longdong area are also significantly different. The relative content of $\mathrm{C}_{27}$ steranes $\left[\mathrm{C}_{27} /\left(\mathrm{C}_{27}+\mathrm{C}_{28}+\mathrm{C}_{29}\right)\right]$ in organicrich shale ranges from 35.17 to $46.41 \%$, with an average of $41.73 \%$. The value of $\mathrm{C}_{28} /\left(\mathrm{C}_{27}+\mathrm{C}_{28}+\mathrm{C}_{29}\right)$ ranges from 15.64 to $23.94 \%$, with an average of $20.03 \%$, and $\mathrm{C}_{29} /$ $\left(\mathrm{C}_{27}+\mathrm{C}_{28}+\mathrm{C}_{29}\right)$ ranges from 33.80 to $42.70 \%$, with an average of $38.24 \%$. While the $\mathrm{C}_{27} /\left(\mathrm{C}_{27}+\mathrm{C}_{28}+\mathrm{C}_{29}\right)$ value of organic-rich mudstone is distributed in $28.53-42.10 \%$, with an average of $34.79 \%$. The $\mathrm{C}_{28} /\left(\mathrm{C}_{27}+\mathrm{C}_{28}+\mathrm{C}_{29}\right)$ value is distributed in $12.10-24.36 \%$, with an average of 


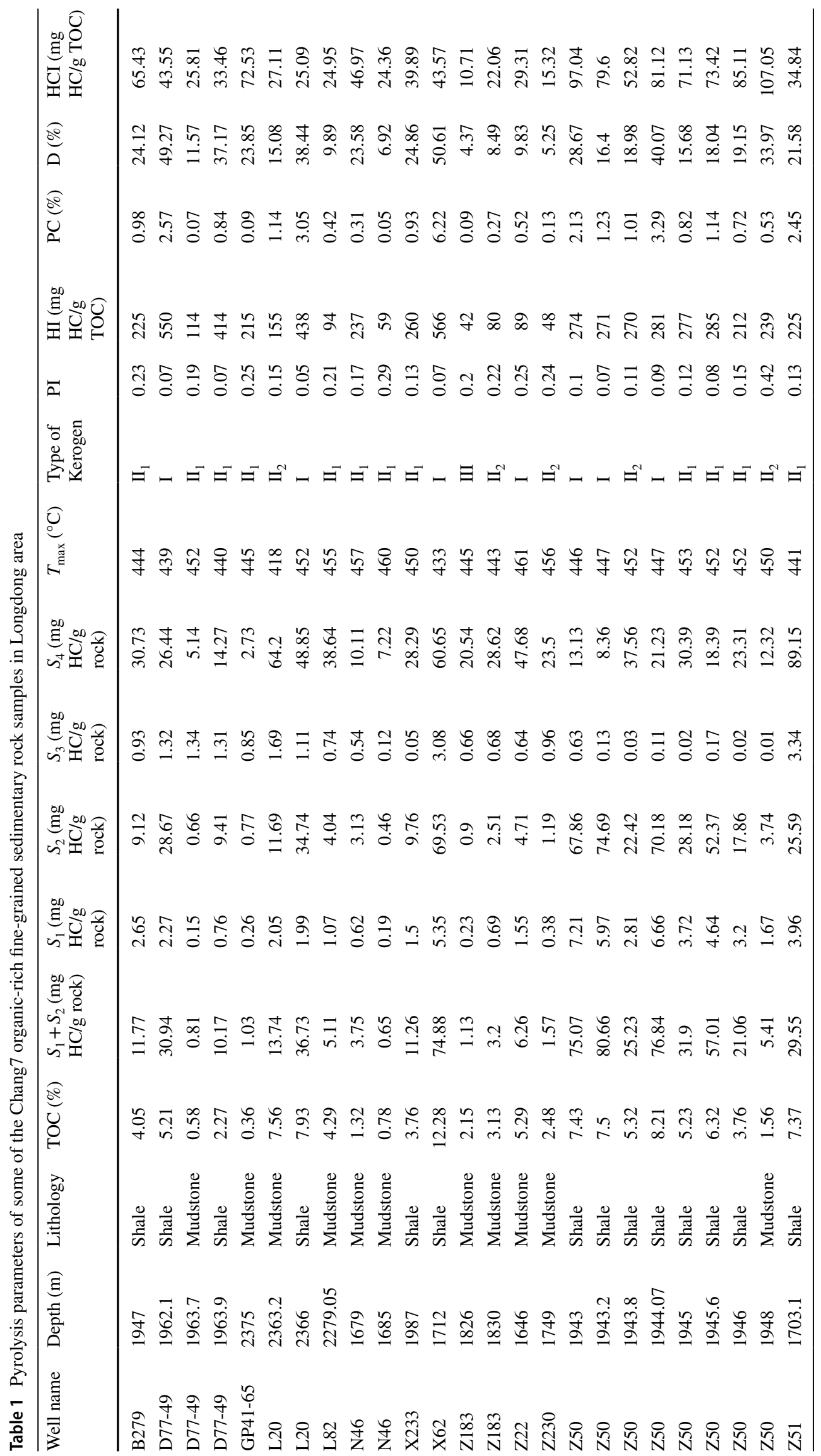


Table 2 Carbon stable isotope data of organic-rich fine-grained sedimentary rocks

\begin{tabular}{llll}
\hline Well name & Depth $(\mathrm{m})$ & Lithology & $\delta^{13} \mathrm{C}(\%)$ \\
\hline L82 & 2279.05 & Shale & -28.90 \\
N70 & 1715.6 & Shale & -29.82 \\
N70 & 1720.3 & Shale & -28.02 \\
N70 & 1712 & Mudstone & -28.14 \\
L20 & 2366 & Mudstone & -28.60 \\
N91 & 1535.08 & Mudstone & -27.31 \\
X233 & 1987 & Mudstone & -28.70 \\
Z70 & 1645.27 & Mudstone & -27.57 \\
Z233 & 1803.78 & Mudstone & -27.25 \\
Z50 & 1943.7 & Mudstone & -26.40 \\
\hline
\end{tabular}

$19.96 \%$, and the $\mathrm{C}_{29} /\left(\mathrm{C}_{27}+\mathrm{C}_{28}+\mathrm{C}_{29}\right)$ value is distributed in $39.02-57.12 \%$, with an average of $45.25 \%$.

\section{Tight oil}

The total hydrocarbon GC analysis (Table 5) shows that the chromatographic peak of the Chang7 tight oil is complete with single peak type and the main peak carbon is $\mathrm{nC}_{15}$. The content of light hydrocarbon components is high, while the content of benzene and toluene is low. The value of $\sum \mathrm{nC}_{21}{ }^{-} / \sum \mathrm{nC}_{22}{ }^{+}$is distributed in 1.23-1.90, the value of $\mathrm{C}_{21+22} / \mathrm{C}_{28+29}$ is distributed in 1.38-1.67. The odd-even predominance is not obvious with CPI of $0.95-1.19$ and OEP of 1.06-1.11. The distribution range of $\mathrm{Pr} / \mathrm{Ph}$ is $0.78-1.04$, $\mathrm{Pr} / \mathrm{n}-\mathrm{C}_{17}$ is $0.42-0.51$, and $\mathrm{Ph} / \mathrm{n}-\mathrm{C}_{18}$ is $0.45-0.66$.

Saturated hydrocarbon GC-MS analysis (Table 6) shows that the distribution range of $\mathrm{G} / \alpha \beta \mathrm{C}_{30} \mathrm{H}$ is $0.05-0.07$, and
Table 3 Maceral data of organic-rich fine-grained sedimentary rocks
Table 4 GC-MS parameters of organic-rich fine-grained sedimentary rocks

\begin{tabular}{|c|c|c|c|c|c|c|c|c|c|}
\hline Well Name & Depth (m) & Lithology & $\begin{array}{l}\text { Type of } \\
\text { Kerogen }\end{array}$ & $\mathrm{a}$ & $\mathrm{b}$ & $\mathrm{c}$ & $\mathrm{d}$ & e & $\mathrm{TI}$ \\
\hline Z153 & 1613.4 & Mudstone & $\mathrm{II}_{1}$ & & & 92 & 7 & 1 & 40 \\
\hline $\mathrm{Z} 153$ & 1657.35 & Mudstone & $\mathrm{II}_{2}$ & & & 90 & 8 & 2 & 37 \\
\hline $\mathrm{Z} 50$ & 1943 & Mudstone & $\mathrm{II}_{2}$ & 50.8 & & & 47.8 & 1.4 & 13.55 \\
\hline $\mathrm{Z} 50$ & 1943.2 & Mudstone & III & 7.8 & & 0.2 & 92 & & -61.1 \\
\hline $\mathrm{Z} 50$ & 1944.07 & Shale & I & & 97.8 & 0.8 & 1.4 & & 97.15 \\
\hline $\mathrm{Z} 50$ & 1945 & Shale & I & & 100 & & & & 100 \\
\hline
\end{tabular}

a: Amorphous (\%); b: Sapropel (\%); c: Exinite (\%); d: Vitrinite (\%); e: Intertinite (\%)

\begin{tabular}{llrllllllll}
\hline Well Name & Lithology & $\mathrm{a}$ & $\mathrm{b}$ & $\mathrm{c}$ & $\mathrm{d}$ & $\mathrm{e}$ & $\mathrm{f}$ & $\mathrm{g}$ & $\mathrm{h}$ & $\mathrm{i}$ \\
\hline Z230 & Shale & 1.00 & 0.16 & 0.08 & 0.13 & 0.35 & 0.22 & 0.43 & 0.22 & 1.51 \\
B460 & Shale & 3.77 & 0.89 & 0.08 & 0.17 & 0.45 & 0.16 & 0.39 & 0.31 & 1.02 \\
X251 & Shale & 14.01 & 1.41 & 0.06 & 0.23 & 0.46 & 0.20 & 0.34 & 0.28 & 1.61 \\
H68 & Shale & 6.01 & 2.34 & 0.07 & 0.21 & 0.45 & 0.17 & 0.37 & 0.20 & 1.62 \\
Z182 & Shale & 2.34 & 0.56 & 0.06 & 0.16 & 0.40 & 0.18 & 0.42 & 0.30 & 1.04 \\
H23 & Shale & 10.08 & 1.10 & 0.04 & 0.17 & 0.40 & 0.24 & 0.36 & 0.26 & 1.81 \\
B279 & Shale & 6.36 & 0.45 & 0.07 & 0.11 & 0.41 & 0.23 & 0.36 & 0.26 & 1.20 \\
L63 & Mudstone & 1.85 & 0.51 & 0.07 & 0.17 & 0.42 & 0.19 & 0.39 & 0.34 & 1.23 \\
L216 & Mudstone & 0.48 & 0.18 & 0.05 & 0.11 & 0.34 & 0.21 & 0.45 & 0.25 & 1.31 \\
N46 & Mudstone & 5.85 & 1.38 & 0.03 & 0.19 & 0.41 & 0.12 & 0.47 & 0.41 & 0.70 \\
B498 & Mudstone & 3.22 & 0.80 & 0.05 & 0.15 & 0.36 & 0.17 & 0.47 & 0.32 & 0.86 \\
Z168 & Mudstone & 2.45 & 0.72 & 0.04 & 0.10 & 0.29 & 0.14 & 0.57 & 0.33 & 0.94 \\
L20 & Mudstone & 3.01 & 0.35 & 0.04 & 0.09 & 0.31 & 0.24 & 0.45 & 0.42 & 1.11 \\
X233 & Mudstone & 9.13 & 1.21 & 0.07 & 0.15 & 0.35 & 0.21 & 0.44 & 0.39 & 0.52 \\
L82 & Mudstone & 6.40 & 0.59 & 0.05 & 0.06 & 0.35 & 0.22 & 0.43 & 0.35 & 1.18 \\
H56 & Mudstone & 6.38 & 0.64 & 0.07 & 0.12 & 0.35 & 0.23 & 0.42 & 0.27 & 1.20 \\
H82 & Mudstone & 5.35 & 0.53 & 0.06 & 0.09 & 0.30 & 0.24 & 0.46 & 0.29 & 0.62 \\
L152 & Mudstone & 1.49 & 0.21 & 0.07 & 0.08 & 0.35 & 0.22 & 0.43 & 0.35 & 0.71 \\
\hline
\end{tabular}

a: Ts/Tm; b: rearrangement hopane/hopane; $\mathrm{c}: \mathrm{C}_{35} /\left(\mathrm{C}_{31}-\mathrm{C}_{35}\right)$ homohopane; d: gammacerane/hopane; e: $\mathrm{C}_{27} /\left(\mathrm{C}_{27}+\mathrm{C}_{28}+\mathrm{C}_{29}\right)$ sterane; f: $\mathrm{C}_{28} /\left(\mathrm{C}_{27}+\mathrm{C}_{28}+\mathrm{C}_{29}\right)$ sterane; $\mathrm{g}: \mathrm{C}_{29} /\left(\mathrm{C}_{27}+\mathrm{C}_{28}+\mathrm{C}_{29}\right)$ sterane; h: diasterane/ regular sterane; i: sterane/hopane 
$\mathrm{C}_{35} /\left(\mathrm{C}_{31}-\mathrm{C}_{35}\right)$ is $0.07-0.08$. The diasterane/regular sterane ranges from 0.17 to 0.25 . The sterane/hopane $(\mathrm{St} / \mathrm{H})$ ranges from 1.30 to 2.52 .

\section{Discussion}

\section{Abundance of organic matter}

A total of 25 Chang7 organic-rich fine-grained sedimentary rock samples in Longdong area were taken to the rock pyrolysis study. There is a significant difference between the organic matter abundance of the organic-rich shale and that of the organic-rich mudstone. For shale samples, the TOC is higher than $4 \%, S_{1}+S_{2}$ is higher than $20 \mathrm{mg} / \mathrm{g}$. While the TOC of mudstone samples is mainly distributed in 1.8-4.0\%, and $S_{1}+S_{2}$ is mainly distributed in 6-20 mg/g (Table 1). According to the grading evaluation criteria for organic matter abundance of high-quality source rocks (Table 7), the organic-rich shale samples of Chang7 Member in Longdong area are mainly organic-rich source rocks and organic matter enrichment layers, while the organic-rich mudstone samples are mainly good source rocks (Fig. 4).

\section{Types of organic matter}

According to the rock pyrolysis parameters of the samples(Table 1), the $T_{\max }$ values of the organic-rich shale samples of Chang7 Member are not much different from that of the mudstone, but the HI values of the organic-rich shale samples are significantly higher than that of the mudstone. Samples of shale and mudstone are clearly distinguished in the distribution diagram of $T_{\max }-\mathrm{HI}$ (Fig. 5, Zhang et al. 2008; Zhang et al. 2015). Shale samples mainly distribute in the section of type $\mathrm{I}-\mathrm{II}_{1}$ (sapropelic kerogen and humic-sapropelic kerogen), while mudstone samples mainly distribute in the section of type $\mathrm{II}_{1}-\mathrm{II}_{2}$ (humic-sapropelic kerogen and sapropelic-humic kerogen).

The types of organic matter can be divided according to the parameters of kerogen carbon isotope and kerogen
Table 5 GC parameters of Chang7 tight oil samples

\begin{tabular}{lllllllll}
\hline Well Name & CPI & OEP & $\begin{array}{l}\sum \mathrm{nC}_{21-} / \\
\sum \mathrm{nC}_{22+}\end{array}$ & $\begin{array}{l}\left(\mathrm{nC}_{21}+\mathrm{nC}_{22}\right) / \\
\left(\mathrm{nC}_{28}+\mathrm{nC}_{29}\right)\end{array}$ & $\mathrm{Pr} / \mathrm{nC}_{17}$ & $\mathrm{Ph} / \mathrm{nC}_{18}$ & $\mathrm{Pr} / \mathrm{Ph}$ & $\begin{array}{l}\text { Main } \\
\text { Peak } \\
\text { Carbon }\end{array}$ \\
\hline N37 & 1.17 & 1.11 & 1.28 & 1.57 & 0.51 & 0.63 & 0.82 & $\mathrm{nC}_{15}$ \\
N45 & 1.18 & 1.06 & 1.33 & 1.52 & 0.48 & 0.63 & 0.80 & $\mathrm{nC}_{17}$ \\
N64 & 1.14 & 1.06 & 1.44 & 1.66 & 0.48 & 0.61 & 0.84 & $\mathrm{nC}_{17}$ \\
N72 & 1.19 & 1.06 & 1.23 & 1.45 & 0.50 & 0.66 & 0.78 & $\mathrm{nC}_{17}$ \\
GP46-66 & 0.95 & 1.08 & 1.90 & 1.76 & 0.42 & 0.47 & 0.94 & $\mathrm{nC}_{15}$ \\
GP40-54 & 1.17 & 1.09 & 1.46 & 1.38 & 0.44 & 0.45 & 1.04 & $\mathrm{nC}_{15}$ \\
\hline
\end{tabular}

Table 6 GC-MS parameters of Chang7 tight oil samples

\begin{tabular}{lllllll}
\hline Well name & $\mathrm{St} / \mathrm{H}$ & $\begin{array}{l}\text { Diasterane/ } \\
\text { regular sterane }\end{array}$ & $T \mathrm{~s} / \mathrm{Tm}$ & $\mathrm{C}_{30} * \mathrm{H} / \mathrm{H}$ & $\mathrm{C}_{35} /\left(\mathrm{C}_{31}-\mathrm{C}_{35}\right)$ & $\mathrm{G} / \mathrm{H}$ \\
\hline N37 & 1.30 & 0.17 & 0.66 & 0.09 & 0.08 & 0.05 \\
N45 & 1.31 & 0.17 & 0.78 & 0.10 & 0.08 & 0.05 \\
N64 & 1.31 & 0.19 & 0.86 & 0.11 & 0.07 & 0.05 \\
N72 & 1.38 & 0.18 & 0.82 & 0.10 & 0.08 & 0.05 \\
GP46-66 & 1.57 & 0.25 & 1.12 & 0.12 & 0.08 & 0.05 \\
GP40-54 & 2.52 & 0.25 & 1.99 & 0.22 & 0.07 & 0.07 \\
\hline
\end{tabular}

Table 7 Grading evaluation criteria for organic abundance of high-quality source rocks (Hou et al. 2011)

\begin{tabular}{llllll}
\hline Level of organic matter abundance & \multicolumn{4}{l}{ Parameters of organic matter abundance } \\
\cline { 2 - 6 } & $\mathrm{C}_{\text {org }}(\%)$ & $\begin{array}{l}\text { Chloroform } \\
\text { asphalt "A" }(\%)\end{array}$ & TOC $(\%)$ & $S_{1}+S_{2}, \mathrm{mg} \mathrm{HC} / \mathrm{g}$ rock & $\mathrm{HC}, \mathrm{mg} / \mathrm{g}$ rock \\
\hline Organic matter enrichment layer & $>6.0$ & $>0.8$ & $>8.0$ & $>42.0$ & $>7.0$ \\
Organic-rich source rock & $3.0-6.0$ & $0.3-0.8$ & $4.0-8.0$ & $20.0-42.0$ & $3.0-7.0$ \\
Good source rock & $1.0-3.0$ & $0.1-0.3$ & $1.8-4.0$ & $6.0-20.0$ & $0.5-3.0$ \\
\hline
\end{tabular}




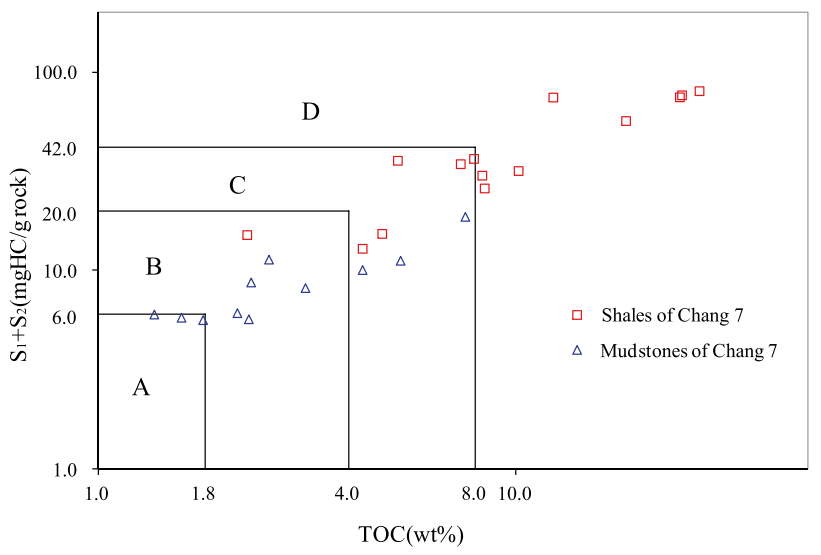

Fig. 4 Evaluation of organic matter abundance of organic-rich finegrained sedimentary rocks. a Non-source rock or poor source rock; $b$ good source rock; c organic-rich source rock; d organic matter enrichment layer (Hou et al. 2008)

maceral analysis. The carbon stable isotope values of shale kerogen are all lighter than $-28 \%$ and the values of TI are all higher than 80 (Tables 2 and 3), indicating that the organic matter type of shale samples is type I ( $\mathrm{Lu}$ et al. 2008; Hou et al. 2011). The stable carbon isotope values of the mudstone samples are of wide range of distribution: 3 of them have carbon isotope values lighter than $-28 \%$, 3 of them are in the range of -26.5 to $-28 \%$ and 1 of them holds a carbon isotope value heavier than $-26.5 \%$ o (Table 2). It shows that the organic matter types of mudstone are type $\mathrm{I}$, type $\mathrm{II}_{1}$ and type $\mathrm{II}_{2}$ (Lu et al. 2008). The TI values of mudstone samples are also in different ranges: 1 of them has TI value ranges from 40 to 80,2 of them are in the range of $0-40$, and 1 of them holds the value less than 0 (Table 3). It shows that the organic matter types of mudstone are type $\mathrm{II}_{1}$, type $\mathrm{II}_{2}$ and type III (Hou et al. 2011) (Fig. 6).

The comprehensive analysis of the samples of Chang7 Member in Longdong area shows that the type of organic matter of shale is type $\mathrm{I}-\mathrm{II}_{1}$, while that of mudstone is mainly type $\mathrm{II}_{1}-\mathrm{II}_{2}$. Shale has a better type of organic matter for oil generation.

\section{Sedimentary environment and source material of organic-rich fine-grained sedimentary rocks}

The Chang7 sedimentary stage was the greatest lacustrine transgression period of the late Triassic in Ordos Basin. The sedimentary background was different from that of the earlymiddle Triassic (Yang 2004). The biomarker, gammacerane $(G)$, mainly represents the stratification of water caused by high salinity and thus becomes an indicator of salinity stratification (Zhang et al. 2008; Hou et al. 2011; Li and Wen 2017). The relative distribution of homohopane $\left(C_{31}-C_{35}\right)$ can be used as an indicator of redox potential (Eh) of source

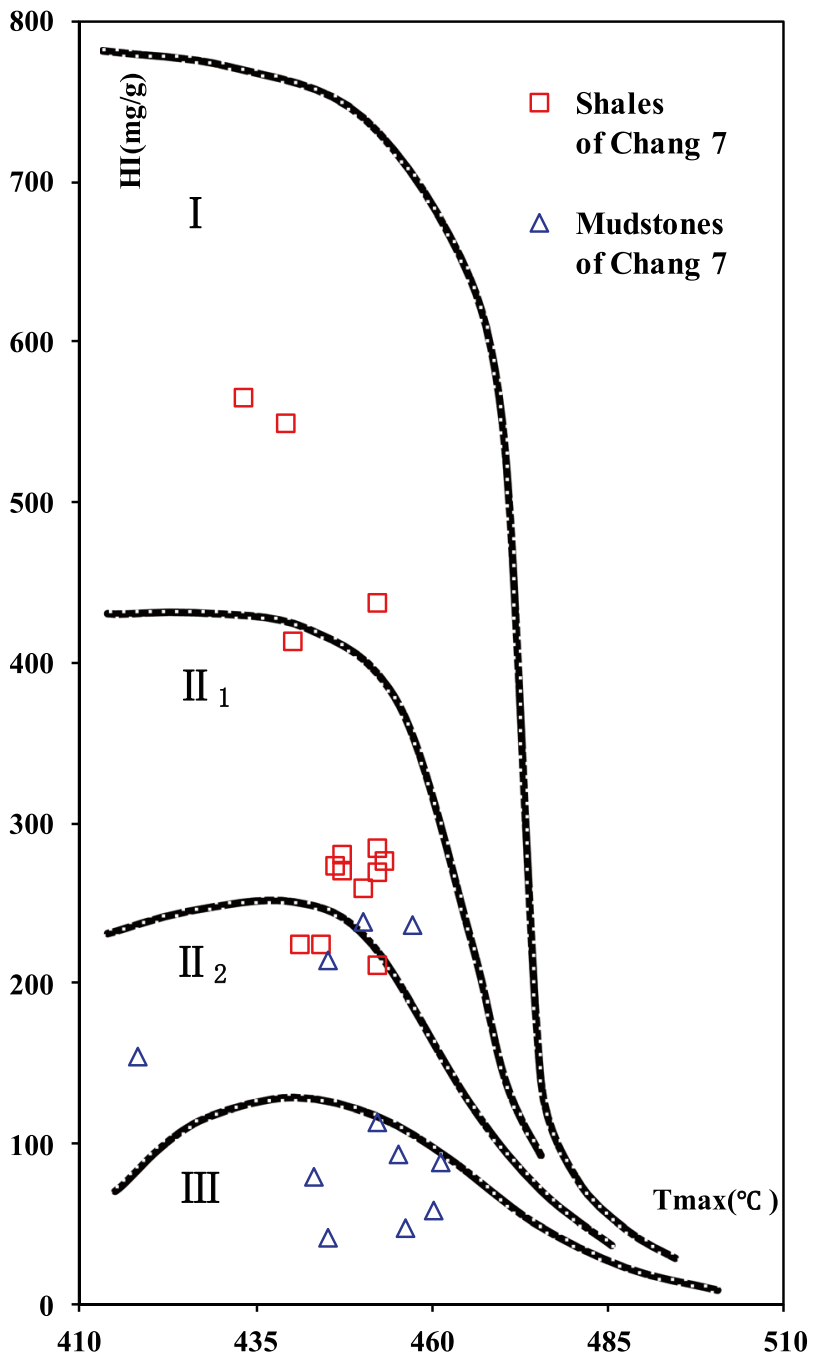

Fig. 5 Relationship between $T_{\max }$ and HI of organic-rich fine-grained sedimentary rocks

rocks during deposition. High $\mathrm{C}_{35} /\left(\mathrm{C}_{31}-\mathrm{C}_{35}\right)$ value generally indicates an anoxic sedimentary environment (Zhang et al. 2008). In general, the $\mathrm{G} / \alpha \beta \mathrm{C}_{30} \mathrm{H}$ value and $\mathrm{C}_{35} /\left(\mathrm{C}_{31}-\mathrm{C}_{35}\right)$ value of the organic-rich shale of Chang7 Member are both significantly higher than that of the organic-rich mudstone (Fig. 7). It shows that compared with the sedimentary period of mudstone, the stratification of water of organic-rich shale is more obvious. Due to the rapid lacustrine transgression in the sedimentary period of shale, the water circulation was blocked as a result of the difference of temperature and salinity between surface water and deep water, creating the hypoxia environment at the bottom. It also indicates that the sedimentary water of the organic-rich shale might be deeper than that of the mudstone.

The relative distribution of $\mathrm{C}_{27}, \mathrm{C}_{28}$ and $\mathrm{C}_{29}$ steranes is commonly used to determine the source input of source 


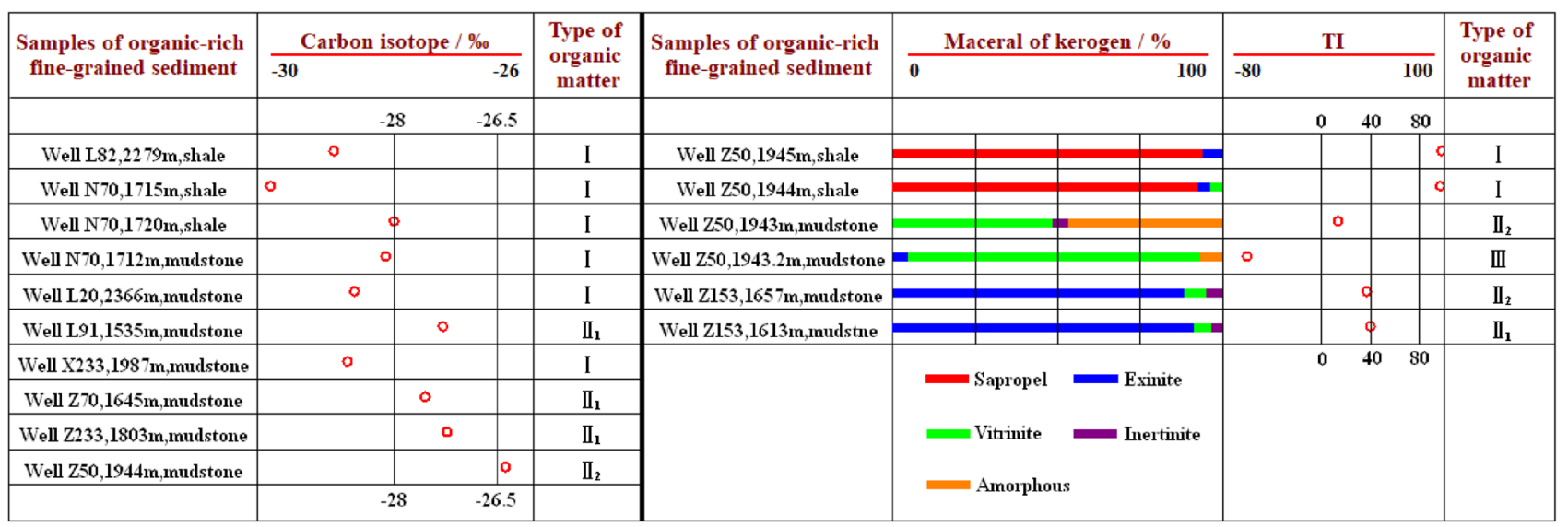

Fig. 6 Distribution of $\delta^{13} \mathrm{C}$ and kerogen maceral of organic-rich fine-grained sedimentary rocks

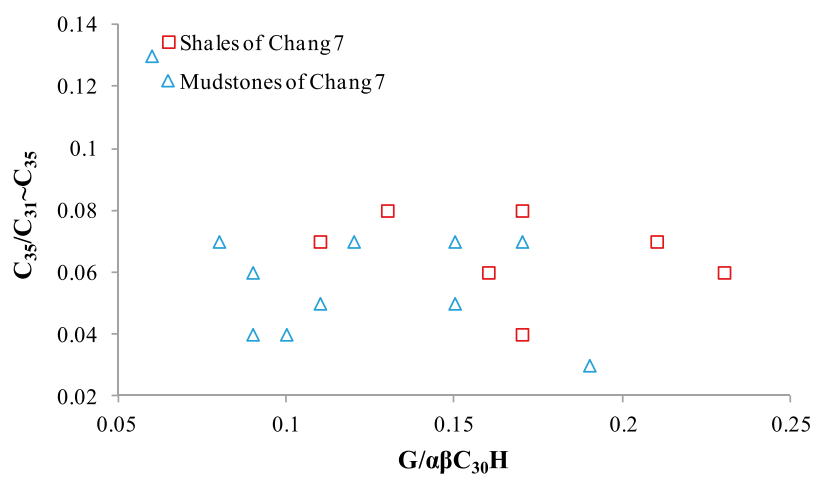

Fig. 7 Distribution of $\mathrm{G} / \alpha \beta \mathrm{C}_{30} \mathrm{H}-\mathrm{C}_{35} /\left(\mathrm{C}_{31}-\mathrm{C}_{35}\right)$

rocks in specific environments. The high content of $\mathrm{C}_{27}$ steranes indicates the source contribution of lower aquatic organisms, while $\mathrm{C}_{29}$ steranes can often indicate the source of higher plants (Zhang et al. 2008; Zhang et al. 2011; Liu et al. 2013). According to the distribution characteristics of sterane series of organic-rich fine-grained sedimentary rocks, the shale samples have significantly high content of $\mathrm{C}_{27}$ steranes, while the mudstone samples have relatively high content of $\mathrm{C}_{29}$ steranes (Fig. 8). It indicates that the source of the organic-rich shale is mainly plankton, while the organic-rich mudstone has a mixed source, which is greatly affected by the terrigenous clastic material.

\section{Source of the tight oil}

The Chang7 tight oil in Longdong area is light oil with low viscosity of which the density on the ground is $0.86 \mathrm{~g} / \mathrm{cm}^{3}$, the viscosity is $4.01-8.71 \mathrm{mPa} \mathrm{s}\left(50^{\circ} \mathrm{C}\right)$ and the freezing point is $16-24{ }^{\circ} \mathrm{C}$. Among the group compositions, the Chang7 tight oil is of high hydrocarbon content and low polar component. The saturated hydrocarbons account for

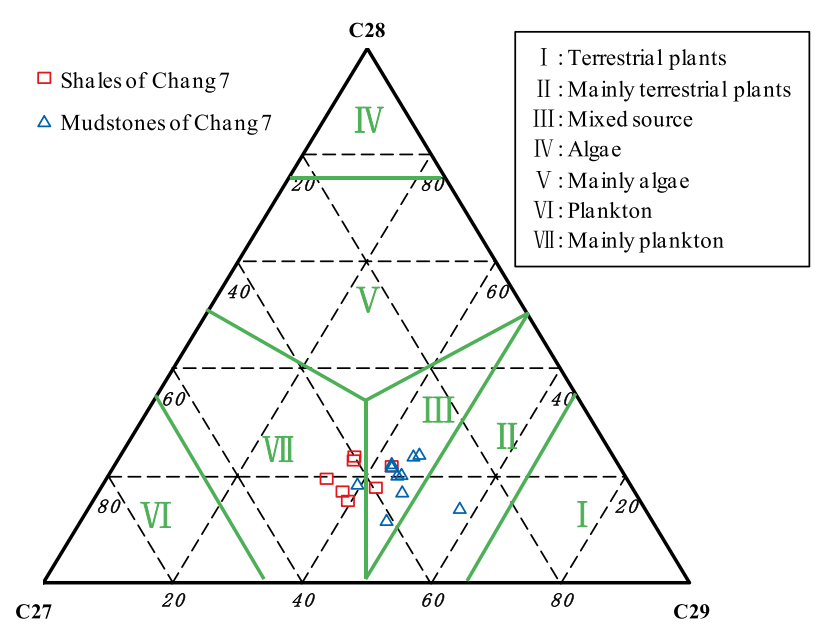

Fig. 8 Distribution of $\mathrm{C}_{27}, \mathrm{C}_{28}, \mathrm{C}_{29}$ steranes

75.8-82.8\%, the content of aromatic hydrocarbons, colloids and asphaltenes is $10.0-12.9 \%, 3.0-7.5 \%$ and $0.8-1.5 \%$ respectively. And the carbon isotope composition is relatively light, with the $\delta^{13} \mathrm{C}_{\mathrm{PDB}}$ value of -31.8 to $-31.5 \%$ o (according to Research Institute of Exploration and Development, PetroChina Changqing Oilfield Company). Based on the analysis of physical properties, the Chang7 tight oil is characterized by the oil from lacustrine source rocks (Wang 2018).

The total hydrocarbon GC analysis of Chang7 tight oil (Table 5) shows that the main peak carbon of the samples are $\mathrm{nC}_{15}$ and $\mathrm{nC}_{17}$, indicates that the source material of organic matter was mainly lower aquatic organisms $(\mathrm{Lu}$ et al. 2008). And the value of $\mathrm{Pr} / \mathrm{Ph}$ is mainly distributed in the range of less than 1.0, indicates that the sedimentary environment was mainly reductive to weak reductive environment (Lu et al. 2008). Saturated hydrocarbon GC-MS analysis (Table 6) shows that the sedimentary water salinity 
of the source of Chang7 tight oil was not high. And Chang7 tight oil may source from plankton or benthic algae, and the clay mineral content of the source rock was low. The study of Oil-source correlation was carried out by the following parameters.

$\mathrm{Pr} / \mathrm{Ph}$ is a common biomarker parameter that characterizes the sedimentary environment and the type of the source material. It is generally believed that the strong phytane advantage $(\mathrm{Pr} / \mathrm{Ph}<0.6)$ indicates the sedimentary environment with strong reduction and high salinity, while the strong pristane advantage indicates the swamp environment (Zhang et al. 2008; Zhang et al. 2011; Deng et al. 2013). However, the overhigh $\mathrm{Pr} / \mathrm{Ph}$ value does not fully reflect the sedimentary environment, but has indicative significance for the input of terrestrial organic matter in the oxidation condition (Hou et al. 2011). Generally, parameters of $\mathrm{Pr} / \mathrm{n}-\mathrm{C}_{17}$ and $\mathrm{Ph} / \mathrm{n}-\mathrm{C}_{18}$ can be used to trace the type of source material and sedimentary environment of oil and source rocks. The distribution range of $\mathrm{Pr} / \mathrm{n}-\mathrm{C}_{17}$ and $\mathrm{Ph} / \mathrm{n}-\mathrm{C}_{18}$ of the Chang7 tight oil samples reflects the sedimentary characteristics of partial salt lake facies. The organic-rich shale samples hold higher $\mathrm{Ph} / \mathrm{nC}_{18}$ value and lower $\mathrm{Pr} / \mathrm{nC}_{17}$ value than organicrich mudstone samples. There is no great numerical difference between the shale and mudstone samples, but in detail, the organic-rich shale indicates the sedimentary environment of salt lake facies, while the organic-rich mudstone reflects the sedimentary characteristics of terrestrial facies or mixed facies (Wang 2018). According to the comparison of $\mathrm{Ph} / \mathrm{n}-\mathrm{C}_{18}$ and $\mathrm{Pr} / \mathrm{n}-\mathrm{C}_{17}$ among the Chang7 tight oil, organicrich shale and mudstone (Fig. 9), the result shows that the Chang7 tight oil in Longdong area has good affinity with the organic-rich shale of Chang7 Member.

The distribution and content of sterane and hopane in tight oil can reflect the characteristics of the source material. High content of sterane and high ratio of sterane and hopane $(\mathrm{St} / \mathrm{H} \geq 1)$ normally indicate that the oil is mainly generated from plankton or benthic algae. While low content of sterane and low St/H value indicate that the oil is sourced from terrestrial or microbial reworked organic matter (Zhang et al. 2011). In the sterane series, the formation of diasterane is related to the acidic clay minerals. Therefore, the low ratio of diasterane and regular sterane in tight oil is the typical characteristic of the anoxic environment and lean clay minerals in source rocks. While the high diasterane/regular sterane value indicates the oil is sourced from clay-rich rocks (Hou et al. 2011). The distribution range of $\mathrm{St} / \mathrm{H}$ and diasterane/ regular sterane value of the oil samples indicates the characteristics of plankton or benthic algae sources with less clay mineral content. And the organic-rich shale samples have higher sterane/hopane value and lower diasterane/regular sterane value than the organic-rich mudstone samples. The comparison shows that the Chang7 tight oil in Longdong

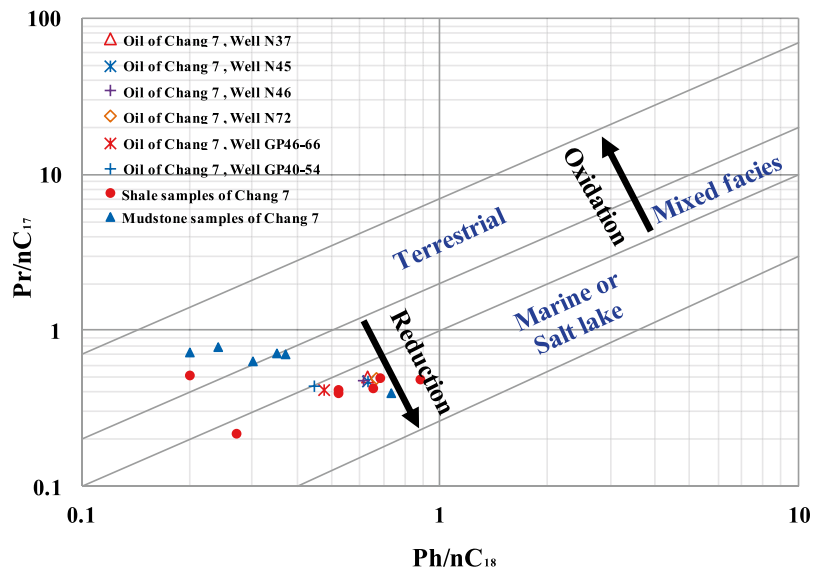

Fig. 9 Distribution of $\mathrm{Ph} / \mathrm{nC}_{18}-\mathrm{Pr} / \mathrm{nC}_{17}$ parameter of Chang7 tight oil and organic-rich fine-grained sedimentary rocks

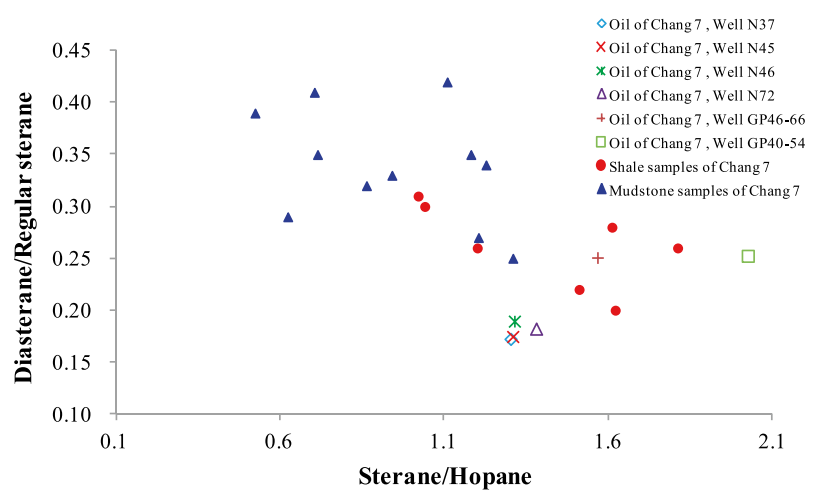

Fig. 10 Distribution of sterane and hopane series of Chang7 tight oil and organic-rich fine-grained sedimentary rocks

area is probably mainly sourced from organic-rich shale of Chang7 Member (Fig. 10).

\section{Conclusions}

The organic petrological indexes that characterize the development degree of fine-grained sedimentary rocks are significantly influenced by the sedimentary environment and preservation conditions. During the Chang7 sedimentary period in Longdong area, the organic-rich shale mainly developed in the deep lacustrine subfacies with relatively stable sedimentary environment. The abundance of organic matter of shale samples is high, and the type of organic matter is type $\mathrm{I}-\mathrm{II}_{1}$. While the organic-rich mudstone mainly developed in the semi-deep lacustrine subfacies with relatively unstable environment. The organic matter abundance of mudstone samples is lower than that of shale, and the type of organic matter is mainly type $\mathrm{II}_{1}-\mathrm{II}_{2}$. 
The biomarker parameters of the sterane and hopane series can indicate the sedimentary environment and source material of sedimentary rocks. The $\mathrm{G} / \alpha \beta \mathrm{C}_{30} \mathrm{H}$ value and $\mathrm{C}_{35} /$ $\left(\mathrm{C}_{31}-\mathrm{C}_{35}\right)$ value of organic-rich shale of Chang7 Member are both higher than that of organic-rich mudstone, indicating that the stratification of sedimentary water was more obvious and the salinity was higher when organic-rich shale was deposited. And the organic-rich shale contains more $\mathrm{C}_{27}$ steranes and less $\mathrm{C}_{29}$ steranes than the organic-rich mudstone, showing that the source material of shale is mainly plankton, while mudstone contains a certain amount of terrigenous clastic material.

The Chang7 tight oil in Longdong area is typical lacustrine oil. Through the study of oil-source correlation, the Chang7 tight oil mainly sourced from the organic-rich shale of Chang7 Member.

Acknowledgements Thanks to Professor Bao Jianping, Professor Zhang Min, Professor He Wenxiang, Teacher Zhu Cuishan, Teacher Chen Qi and fellow students of Yangtze University for many useful suggestions and careful guidance to paper.

Funding This research was funded by the China Geological Survey (Grant No. 1212011220762), Science and Technology Innovation Project of CNPC (Grant No. 2008D-5006-01-10).

\section{Compliance with ethical standards}

Conflict of interest The authors declare that they have no conflict of interest.

Open Access This article is licensed under a Creative Commons Attribution 4.0 International License, which permits use, sharing, adaptation, distribution and reproduction in any medium or format, as long as you give appropriate credit to the original author(s) and the source, provide a link to the Creative Commons licence, and indicate if changes were made. The images or other third party material in this article are included in the article's Creative Commons licence, unless indicated otherwise in a credit line to the material. If material is not included in the article's Creative Commons licence and your intended use is not permitted by statutory regulation or exceeds the permitted use, you will need to obtain permission directly from the copyright holder. To view a copy of this licence, visit http://creativecommons.org/licenses/by/4.0/.

\section{References}

Aplin AC, Macquaker JSH (2011) Mudstone diversity: origin and implications for source, seal and reservoir properties in petroleum system. AAPG Bull 95(12):2031-2059

Deng N, Zhang Z, Wang F, Liang Q, Li Y, Li W, Lu C, Zhao S, Luo M (2013) Geochemical characteristics and oil-source correlation of crude oil in the Zhenjing area, southern Ordos Basin. Nat Gas Geosci 24(3):604-611

Du J, Liu H, Ma D, Fu J, Wang Y, Zhou T (2014) Discussion on effective development techniques for continental tight oil in China. Pet Explor Dev 41(2):198-205
Fu J, Deng X, Chu M, Zhang H, Li S (2013) Features of deepwater lithofacies, Yangchang Formation in Ordos Basin and its petroleum significance. Acta Sedimentol Sin 31(5):928-938

Ghanizadeh A, Clarkson CR, Aquino S, Ardakani OH, Sanei H (2015) Petrophysical and geomechanical characteristics of Canadian tight oil and liquid-rich gas reservoirs: pore network and permeability characterization. Fuel 153:664-681

Hao Z, Fei H, Hao Q, Turner S (2014) Major breakthroughs in geological theory, key techniques and exploration of tight oil in China. Acta Geol Sin 88(1):362-363

Hou D, Feng Z (2011) Oil and gas geochemistry. Petroleum Industry Press, Beijing

Hu H, Zeng Z, Liu J (2015) Key elements controlling oil accumulation within the tight sandstones. J Earth Sci 26(3):328-342

Hu S, Zhu R, Wu S, Bai B, Yang Z, Cui J (2018) Exploration and development of continental tight oil in China. Pet Explor Dev 45(4):737-748

Jia C, Zheng M, Zhang Y (2012) Unconventional hydrocarbon resources in China and the prospect of exploration and development. Pet Explor Dev 39(2):129-136

Jiang Z, Liang C, Wu J, Zhang J, Zhang W, Wang Y, Liu H, Chen $X$ (2013) Several issues in sedimentological studies on hydrocarbon-bearing fine-grained sedimentary rocks. Acta Petrol Sin 34(6):1031-1039

Ko LT, Loucks RG, Zhang T, Ruppel SC, Shao D (2016) Pore and pore network evaluation of upper cretaceous Boquillas (eagle fordequivalent) mudrocks: results from gold tube pyrolysis experiments. AAPG Bull 100(11):1693-1722

Li F, Wang D, Zhang Q, Xu X (2006) Sedmientary facies characteristic and sequence stratigraphy analysis of Yanchang formation in Longdong area. Ordos Basin Acta Sedimentol Sin 24(4):549-554

Li P, Zheng M, Bi H, Wu S, Wang X (2017) Pore throat structure and fractal characteristics of tight oil sandstone: a case study in the Ordos Basin, China. J Pet Sci Eng 149:665-674

Li W, Wen Z (2017) Characteristics of fine-grained sediments from the 7th member of the Yangchang formation in the Southwestern Ordos Basin. Acta Geol Sin 91(5):1120-1129

Liang C (2017) The sedimentation and reservoir formation mechanism of hydrocarbon-bearing fine-grained sedimentary rocks. Dissertation, China University of Geosciences

Liang H, Li X, Ma Q, Liang H, Luo Q, Chen X, Bai G, Zhang Q, Meng Y (2014) Geological features and exploration potential of Permian Tiaohu Formation tight oil, Santanghu Basin, NW China. Pet Explor Dev 41(5):616-627

Liu G, Yang W, Feng Y, Ma H, Du Y (2013) Geochemical characteristics and genetic types of crude oil from Yangchang Formation in Longdong Area Ordos Basin. Earth Sci Front 20(2):108-115

Lu S, Zhang M, Zhong N (2008) Oil and gas geochemistry. Petroleum Industry Press, Beijing

Lucy T, Robert G, Zhang TW (2016) Pore and pore network evaluation of Upper Cretaceous Boquillas (Eagle Ford-equivalent) mudrocks: results from gold tube pyrolysis experiments. AAPG Bull 100(11):1693-1722

Nole M, Daigle H, Milliken KL, Prodanovic M (2016) A method for estimating microporosity of fine-grained sediments and sedimentary rocks via scanning electron microscope image analysis. Sedimentology 63(6):1507-1521

Picard MD (1971) Classification of fine-grained sedimentary rocks. J Sediment Res 41(1):179-195

Pommer M, Milliken K (2015) Pore types and pore-size distributions across thermal maturity, Eagle Ford Formation, southern Texas. AAPG Bull 99(9):1713-1744

Pu X, Zhou L, Han W, Zhou J, Wang W, Zhang W, Chen S, Shi Z, Liu F (2016) Geologic features of fine-grained facies sedimentation and tight oil exploration: a case from the second Member

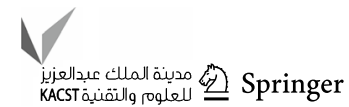


of Paleogene Kongdian Formation of Cangdong sag, Bohai Bay Basin. Pet Explor Dev 43(1):24-33

Wang Q (2018) Geochemical characteristics and genesis of tight and shale oil from the 7th member of Yanchang formation in Ordos Basin. Dissertation, Guangzhou Institute of Geochemistry, Chinese Academy of Sciences

Xu L, Zhou L, Zhang Y, Dang B (2006) Characteristics and tectonic setting of tectono-stress field of Ordos Basin. Geotecton Metallog 30(4):455-462

Yang H (2004) Deposition system and oil accumulation research of Yangchang formation in Triassic, Ordos Basin. Dissertation, Chengdu University of Technology

Yang H, Zhang W, Peng P, Liu F, Luo L (2016) Oil detailed classification and oil-source correlation of Mesozonic lacustrine oil in Ordos Basin. J Earth Sci Environ 38(2):196-205

Yang R, Yin W, Fan A, Han Z, Van L (2017) Fine-grained, lacustrine gravity-flow deposits and their hydrocarbon significance in the Triassic Yanchang Formation in southern Ordos Basin. J Palaeogeogr 19(5):791-806

Yuan X, Lin S, Liu Q, Yao J, Wang L, Guo H, Deng X, Cheng D (2015) Lacustrine fine-grained sedimentary features and organicrich shale distribution pattern: a case study of Chang 7 Member of Triassic Yanchang Formation in Ordos Basin, NW China. Pet Explor Dev 42(1):34-43

Zhang S, Liu H, Chen S, Wang Y, Pu X, Zhang K, Han W (2017) Classification scheme for lithofacies of fine-grained sedimentary rocks in faulted basins of eastern China. Acta Geol Sin 91(5):1108-1119
Zhang W, Yang H, Yang W, Wu K, Liu F (2015) Assessment of geological characteristics of lacustrine shale oil reservoir in Chang7 member of Yanchang formation, Ordos Basin. Acta Geochim 44(5):505-515

Zhang X (2017) Research on reservoir characteristics and diagenesis evolution of the neogene fine-grained sedimentary rocks in the Northwestern Qaidam Basin. Dissertation, Chinese Academy of Geological Science

Zhang X, Duan Y, He J, Wu B, Xu L (2011) Geochemical characteristics of crude oil in lower part of Yangchang formation and correlation of oil source in Huaqing area of Ordos Basin. Nat Gas Geosci 22(5):866-873

Zhang Y, Zeng J, Dai Z, Viswanathan H, Xiao T, Ma Y, Feng X (2018) Experimental investigation on oil migration and accumulation in tight sandstones. J Pet Sci Eng 160:267-275

Zhao Z, Guo Y, Wang Y, Lin D (2012) Study progress in tectonic evolution and paleogeography of Ordos Basin. Spec Oil Gas Reservoirs 19(5): 15-21

Zou C, Tao S, Hou L, Zhu R, Yuan X (2013) Unconventional petroleum geology. Geological Publishing House, Beijing

Publisher's Note Springer Nature remains neutral with regard to jurisdictional claims in published maps and institutional affiliations. 